\title{
THE CIRCULAR ECONOMY APPROACH FOR REDUCING FOOD WASTE: A SYSTEMATIC REVIEW
}

Kamilla da Silva Duarte ${ }^{1}$, https://orcid.org/0000-0002-4414-989X, kamilla_duarte96@hotmail.com

Thales Abreu da Costa Lima ${ }^{1}$, https://orcid.org/0000-0002-7896-9191, thalescamera@gmail.com

Leticia Rodrigues Alves ${ }^{1}$, https://orcid.org/0000-0003-3034-2127, leticiarodrigues.alves4@ gmail.com

Patrícia Andréa do Prado Rios ${ }^{2}$, https://orcid.org/0000-0002-4155-3205, patricia.prado@ northumbria.ac.uk Wladmir Henriques Motta ${ }^{1}$, https://orcid.org/0000-0002-8254-1278, wladmir.motta@ cefet-rj.br

1 Federal Center for Technological Education Celso Suckow da Fonseca, 20271-204, Nova Iguaçu-RJ, Brazil

2 Northumbria University, Newcastle Upon Tyne NE7 7YT, Reino Unido

Submitted: 25/10/2021. Accepted: 30/12/2021

Published: 31/12/2021

\begin{abstract}
Purpose: This study performs a systematic review through a global analysis of selected articles on food waste and the Circular Economy in the period between 2011 and 2020, indexed in the Scopus and Web of Science databases.
\end{abstract}

Methodology/Approach: It performs a qualitative analysis of 19 selected articles to identify how the Circular Economy can be used in the strategy to reduce food waste.

Findings: The main focus is to avoid a global collapse, provoked by the unrestrained increase in production and consumption since the industrial revolution, intensified in the middle of the 20th century. That culminated in the degradation of the soil, seas and the consequent air pollution caused by all these factors, and in the social issue, the increase in social inequality between countries and people, and the evolution of food insecurity, especially among the most vulnerable.

Research Limitation/implication: This research contributes to academia and society, by identifying principal authors, keywords, and gaps in the selected literature and then, proposes suggestions for future research.

Originality/Value of paper: The growing waste of food has directly affected the economic, social and environmental spheres, a subject widely discussed and included in the Sustainable Development goals of 2030.

KEYWORD: circular economy, waste, food, consumerism, climate change

\section{A ABORDAGEM DA ECONOMIA CIRCULAR PARA A REDUÇÃO DOS RESÍDUOS ALIMENTARES: UMA REVISÃO SISTEMÁTICA}

\section{RESUMO}

Objetivo: Este estudo realiza uma revisão sistemática por meio de uma análise global de artigos selecionados sobre desperdício de alimentos e a Economia Circular no período de 2011 a 2020, indexados nas bases de dados Scopus e Web of Science.

Metodologia / Abordagem: realiza uma análise qualitativa de 19 artigos selecionados para identificar como a Economia Circular pode ser utilizada na estratégia de redução do desperdício de alimentos.

Resultados: O foco principal é evitar um colapso global, provocado pelo aumento desenfreado da produção e do consumo desde a revolução industrial, intensificado em meados do século XX. Fatores que degradam o solo, os mares e geram poluição do ar, e que impactam na questão social, elevando a desigualdade social entre países e povos, e a evolução da insegurança alimentar, especialmente entre os mais vulneráveis.

Limitação / implicação da pesquisa: Esta pesquisa contribui para a academia e a sociedade, ao identificar os principais autores, palavras-chave e lacunas na literatura selecionada e, a seguir, propor sugestões para pesquisas futuras.

Originalidade: $\mathrm{O}$ artigo resalta que o crescente desperdício de alimentos tem afetado diretamente as esferas econômica, social e ambiental, assunto amplamente discutido e incluído nas metas de Desenvolvimento Sustentável para 2030.

Palavras-chaves: economia circular, desperdício, alimentos, consumismo, mudança ambiental 


\section{INTRODUCTION}

Approximately one third of food produced for consumption is discarded each year worldwide (FAO, 2021). Such a waste constitutes a serious threat to food security, the economy and the environment (Abiad \& Meho, 2018). Due to the risk to sustainability in its various aspects, food waste is an issue that is reflected in the 2030 Sustainable Development agenda and is specifically portrayed in goal 12.3 of the Sustainable Development Goals (SDGs). This goal foresees a halving of the waste generated by food waste by 2030 (FAO, 2019).

A relevant aspect in the organizational structure of a company can impact its decision hierarchy (Cruz \& Araujo, 2021). Among the alternatives proposed to combat this waste, the Circular Economy (CE) has been increasingly gaining strength in the academic field due to its bias applied mainly to industrial practices and business models (McCarthy et al., 2019). The current economics model is considered a linear model, which consists of "producing, using and disposing" (Lehtokunnas et al., 2020).

The circular model, on the other hand, is based on the proposal to maintain materials within the production circle, in order to virtually eliminate waste, through the combination of activities such as reduction, reuse and recycling (Kirchher et al., 2017; EMF, 2013), commonly known as 3Rs which today is designated as 9Rs (considering here also resource revaluation, income redistribution, improving relationships, resilience adaptability, revaluation scale value and economy restructuring), where there is a proposal that goes beyond reducing consumption to the minimum necessary, reusing what can still be used and recycled, transforming waste into a resource for a new life (product), pointing to an even greater responsibility for all actors involved during the product's life cycle, including here the consumer, thus updating the $9 \mathrm{Rs}$ in reduce, repair, reuse, recycle, recover, refurbish, repurpose, refuse, remanufacture, rethink (Van Buren et al., 2016; Potting et al., 2017).

From this perspective, this study seeks to identify whether and how existing studies in the CE area have offered proposals for the reduction or elimination of food waste through a circular model. Therefore, it uses a systematic literature review as a methodological approach. Such an approach uses systematic methods to select, analyze and evaluate a large dataset from existing studies (Donato \& Donato, 2019). Systematic reviews follow specific protocols and are essential in order to integrate studies carried out on a particular topic (Galvão \& Ricarte, 2019; Boloy et al, 2021). In this field of knowledge, whose challenges are urgent, identifying trends and solutions with potential for immediate applicability becomes relevant for different actors such as researchers, government entities, companies and civil society. Different of other systematic reviews, like Boloy et al (2021) this study performs a systematic review about food waste and the Circular Economy in the period between 2011 and 2020, articles indexed in the Scopus and Web of Science databases.

The article is organized into five sections. After contextualizing the problem in its introductory section, the concepts of CE and food waste are reviewed in section two. Next, methods and data collection are described in section three. The fourth section analyzes and discusses the collected data. The fifth and last section concludes this article by identifying its limitations and pointing out possibilities for future research.

\section{CIRCULAR ECONOMY AND THE FOOD WASTE REDUCTION}

One of the main objectives of the circular economy is the elaboration of a closed-loop process. In the context of food waste, the purpose of this system is to increase the efficiency of procedures related to the 9Rs and promote a deceleration of flows, ensuring that food is used to its full potential before suffering waste/disposal (Lehtokunnas et al., 2020).

Borrello et al., (2020) shows that circular business models are effective in facing and facing the challenges of society in contributing to the SDGs, especially in promoting an updated approach in favor of sustainable measures of industrial systems, rethinking the organization of supply chains. 
Reducing food waste is one of the food waste management practices, whether in improving the distribution of food that is suitable for human consumption or in the transformation of this food waste into products to produce biomaterials, energy, fertilizer, etc. (Borrello et al., 2020).

The proper disposal of food waste, through organic solid waste management programs, as proposed by the EC, has the potential to collaborate with recycling and the reduction in the generation of these wastes (Durrani, 2019).

\section{METHODOLOGY}

The text addresses the circular economy as an aid to practices that can more efficiently reduce, reuse, and distribute food that would otherwise be wasted by industries, retail businesses, and civil society in general. Research was carried out on journals from different areas of the world, scientific articles that supported this research. The article was prepared using a qualitative method, as a bibliometric analysis was carried out with selected articles, as can be analyzed in step 1 of the results. In addition to stage 2 , conducted through meta-analysis and reading selected articles, producing a qualitative analysis.

Develop information guarantees potential for learning (Concolato et al, 2020; Sordan et al, 2021; Germano et al, 2021) and discoveries to generate value for students and researchers, consequently leading to sustainable growth for future research in favor of academic evolution (Sousa et al, 2018). In this paper, an analysis will be proposed based on Lotka's law of research productivity, where the author came to the conclusion that the concentration of scientific knowledge came from a small part of the authors and Zipf's law of word frequency, which identifies the use of a word repeatedly in a scientific paper, and these most used words elucidate the topic addressed in the research. Data collection was obtained during the months of May and June 2021, according to the guidelines given below (Mathankar, 2018).

For the preparation of this research, a guiding question was stipulated, the research was analyzed in reliable data sources, acquired mainly from indexed journals, establishing inclusion and exclusion criteria to identify the quality, relevance and framework of the papers found, in order to bring data and display them in an accessible way and interpret their results.

\section{Guiding Question}

In order to verify the ways of reducing food waste that directly impact society, the following question arose: "How can the Circular Economy assist in reducing food waste?"

\section{Database Used}

In order to select reliable research with provenance that met the guiding question, being used two databases: Web of Science and Scopus, respectively. The first base applied, was the Web of Science, using the main collection of this, in the basic search, searching the term Circular Economy and Food Waste in English, "Circular Economy" And "Food Waste", in the topical place to search in the fields title, abstract, author's keywords and Keywords plus, placed in quotes, so that this search had a correct and satisfactory result. In Scopus, the same procedure was performed, so that the results were made in an equivalent manner to what was done in the Web of Science.

First, a complete search was conducted using the keywords "Circular Economy" and "Food Waste" and the return obtained was 275 documents in the Web of Science Base and 275 documents in the Scopus Base, figure 1, totaling 550 documents.

The references that met the inclusion criteria were evaluated, taking into account the publication period. The search was restricted to articles published between 2011 and 2020. Articles published in the year 2021 were removed, since this is the year in which the research is being conducted and publications vary throughout the year. For eligibility of articles, the criterion of similarity to the theme 
of the subject and the journal relevance; the others were excluded, along with the duplicates found in the databases.

\section{Inclusion and exclusion criteria for article selection}

Some criteria were used to identify and select the files, as discussed below.

\section{Global Analysis}

They were excluded:

1- Articles with original language different from English, Spanish and Portuguese.

They included:

1- Publication year (2011-2020)

2- Type of publication scientific article

3- Original language of the publication in English, Spanish or Portuguese

4- Duplicate articles

\section{Analysis of the Selected Articles}

They were excluded:

1- Articles with original language different from English, Spanish and Portuguese.

2- Articles with titles and abstracts unrelated to the guiding question

They included:

1- Publication year (2011-2020)

2- Type of publication scientific article

3- Free access

4- Original language of publication English, Spanish or Portuguese.

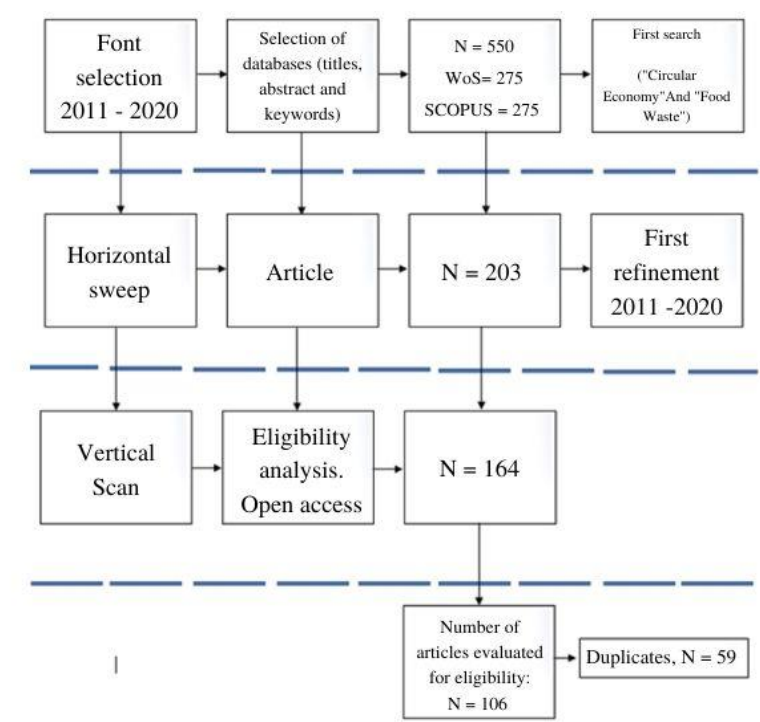

Figure 1: Flowchart Integration Scopus and Web of Science

Source: Prepared by the authors (2021). Adapted from Sordan et al (2021) 


\section{Data Collection}

The gathering of data from the works, was collected to be displayed in an understandable way, the bibliometric information of the search in the research bases, were exported and analyzed in the statistical tool RStudio with the help of the Bibliometrix software. Information was and exported to Microsoft Office Excel spreadsheets, and their graphs saved in internal folders of the authors' computers and in their respective storage clouds. A global bibliometry of articles originating from the years between 2011 and 2020 was carried out. Publications written in English, Spanish and Portuguese, excluding those that were duplicates. Next, with the purpose of gauging the quality of the articles and the relation with the proposal chosen for this systematic review, which intends to understand the correlations and connections between Circular Economy and food waste. All titles and abstracts were read for a selection. Articles unrelated to the proposal were excluded.

\section{Interpretation of Results}

\section{Step 1 (Comprehensive analysis)}

The information collected generated tables and graphs obtained by the Bibliometrix program, free version of an application that analyzes all scientific production published in academic journals. The consequent effects of this data analysis will be verified in the next topic of this study.

In WEB OF SCIENCE 275 files were found, published between the years 2011 and 2020, of these 191 articles and only 81 held open access (see Graph 1).

\section{Graph 1: Publication x Year of Publication in the Web of Science}

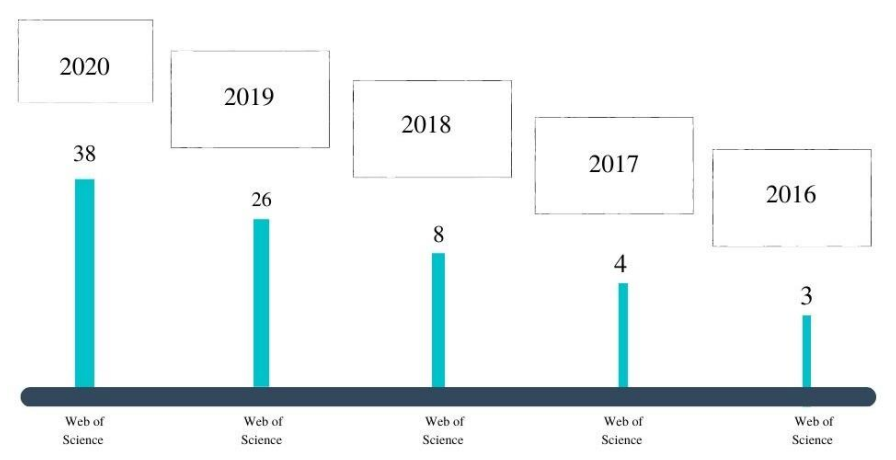

Source: Prepared by the authors (2021)

It's worth noting that the chosen keywords showed that only as of 2016, Circular Economy and Food Waste started appearing together in article titles or in their abstracts, "keywords" and "keywordsplus". In that same year, articles started to relate this Circular Economy economic model to food waste. 2020 was the year with the highest number of annual publications, with 38 articles. What one might notice is the expressive increase in releases as of 2016, peaking in 2020.

The content was exported through the path: export, other file formats, selecting records from 1 to 81 , recording the complete content and saving in a file called Bibtex, for the data to be analyzed by the Bibliometrix tool, through the help of the computer program RStudio. This software contains complete information of the articles, such as: Publication Type, Article Number, Document Type, Researcher Ids, ORCIDs, Funding Text, ISSN, eISSN, Funding Orgs, Access Designations, Supplement, Special Issue, IDS Number, UT (Unique WOS ID), Pubmed Id, Open Date of Export among others. And its statistical data, tables, graphs, etc.

The search conducted in the Scopus database selected 275 articles, published between the years 2016 and 2020, of these 122 articles and 83 open files, which were also analyzed regarding the selection of research eligibility related to the proposal of this systematic review, and follow the information of the last five years in Graph 2. 
Graph 2: Publication x Year of Publication of SCOPUS

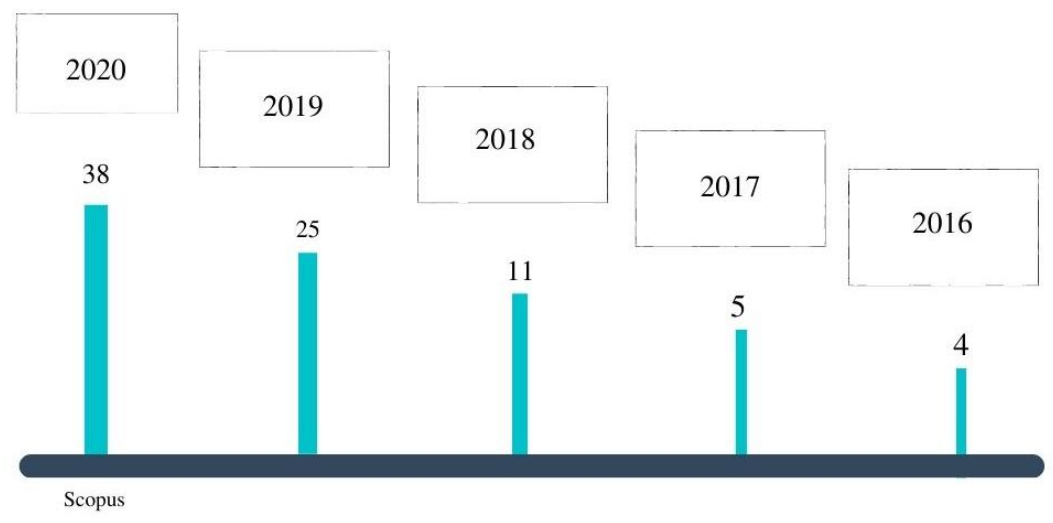

Source: Prepared by the authors (2021)

Information concerning the quantity of total articles selected by the search on databases, with the keywords "Circular Economy" and "Food Waste", one noticed an equality in the first search, both Web of Science and Scopus, had 275 articles. In the requirement, open articles, there was a disparity between the bases, with 190 searches in Web of Science and 122 in Scopus. Both databases have many repeated articles, decreasing the total number of searches for the overall analysis, reaching 105 articles, 81 articles of them were indexed in the Web of Science and 24 in Scopus index. Graph 3 below depicts this scenario.

Graph 3: Number of Articles Located by Base

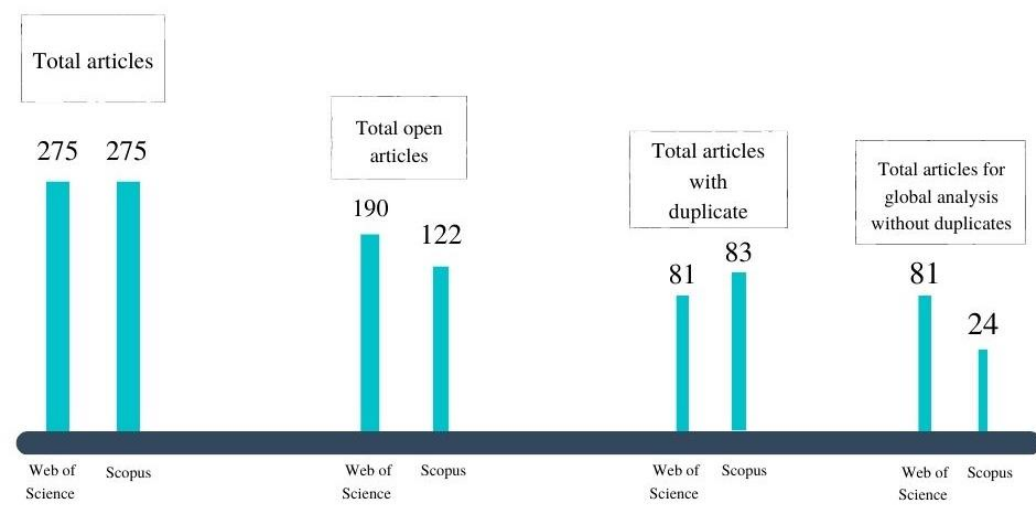

Source: Authors (2021)

\section{RESULTS}

\section{Step 1 (Comprehensive analysis)}

The reference was made based on the publications made with the keywords "Circular Economy" and "Food Waste" and that were inserted in the titles, abstract or in the keywords themselves, then the graph lists the authors with the most publications. Second Lokta's law analyzes the scientific productivity of the authors, verifies the contribution of each one to the scientific development in their area of knowledge (Rodrigues, 2015). In Figure 4, it is presented 20 authors who have developed more about the chosen theme. Bringing as the most productive authors Irabien A, Laso J, Margallo M, Aldaco R and Bala A, with 3 publications each. And the other authors with two or one publication each. Therefore, it is possible to analyze that there is no high concentration of publications in a particular set, but a large number of authors disclosure. 


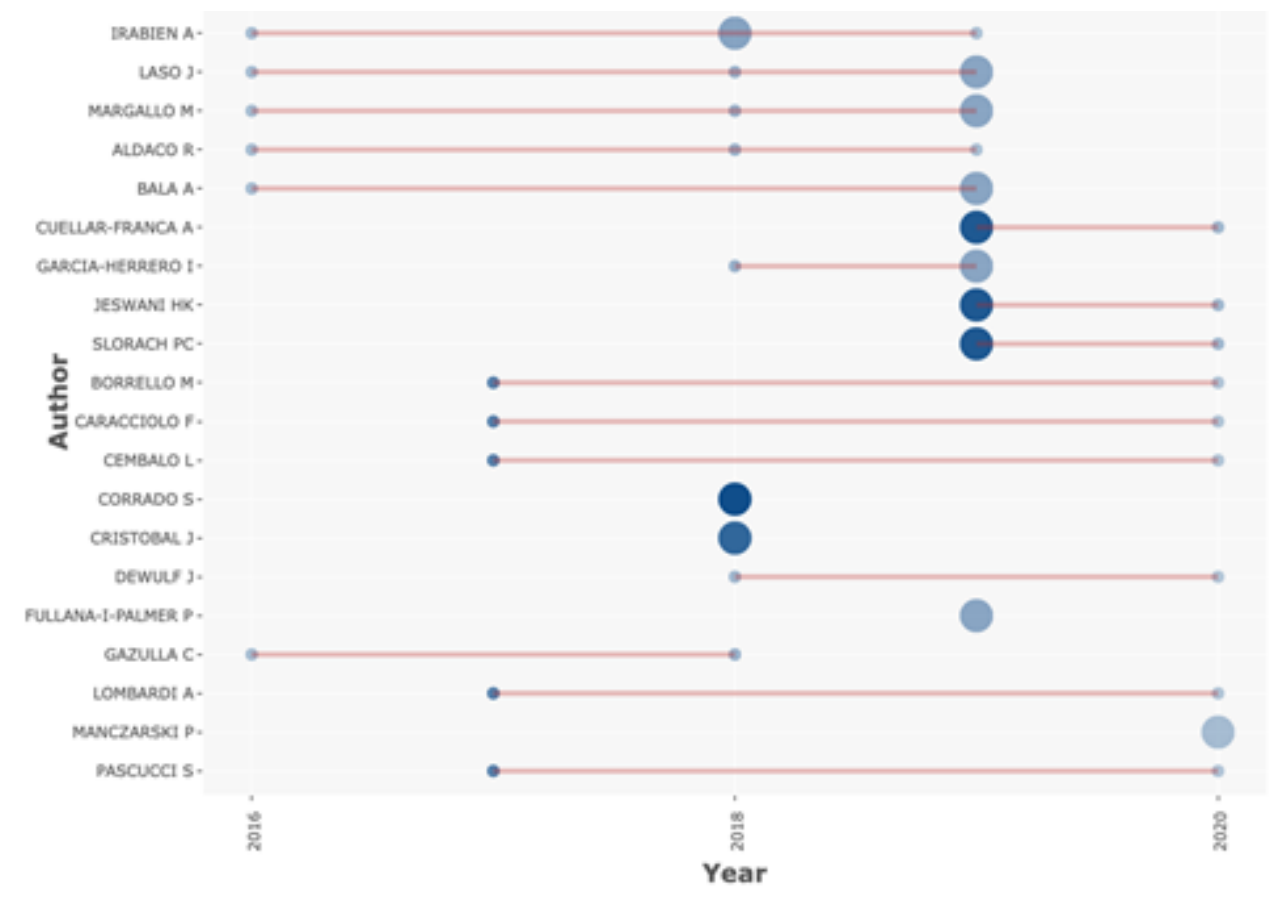

Figure 4: Authors with most publications

Source: Blibiometrix (2021)

Globally, knowledge makes more and more contributor to researches of authors of different characteristics, each country contributing with their theses on a given subject. The effect of citation is analyzed in graph 4, where in the WEB OF SCIENCE base were found 292 citations from different authors between the year 2016 and 2019, of which 76 citations were from the author Borrelo M. in the year 2017, already more current researches of the year 2019 the highest citation was from the author Protecentese A. that obtained 39 citations. It is possible to realize that there was a small decrease in citations for the current year, but still continues with significant references.

Graph 4: Most cited documents globally Web of Science

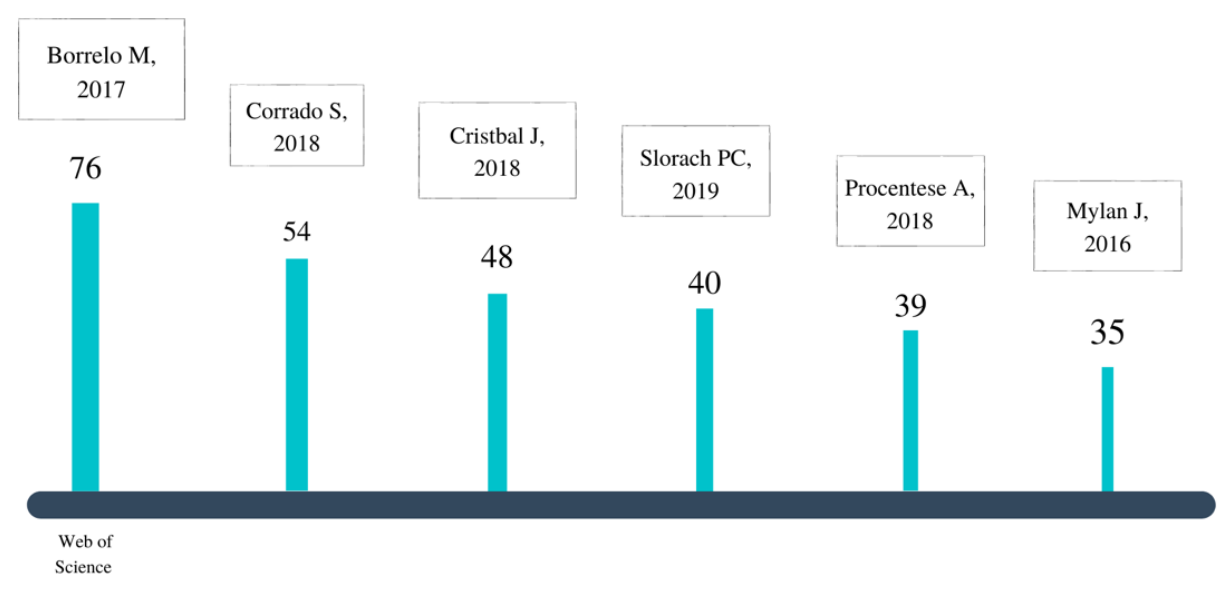

Source: Prepared by the authors (2021)

In parallel to the analysis of the previous base, Scopus presents (428) documents cited from different authors, graph 5, showing a dissimilarity of citations globally, but the highest number of citations occurred by the author Jurgilevich A. in the year 2016 with (151). Currently the most cited articles in the referenced base is the author Sloraach PC. with (46) citations, however in parallel to the most cited author between the years 2016 and 2019, it was possible to identify that there was a drop of more than half of references, even so still has 6 documents as in WEB OF SCIENCE. 
Graph 5: Documents most cited globally in Scopus

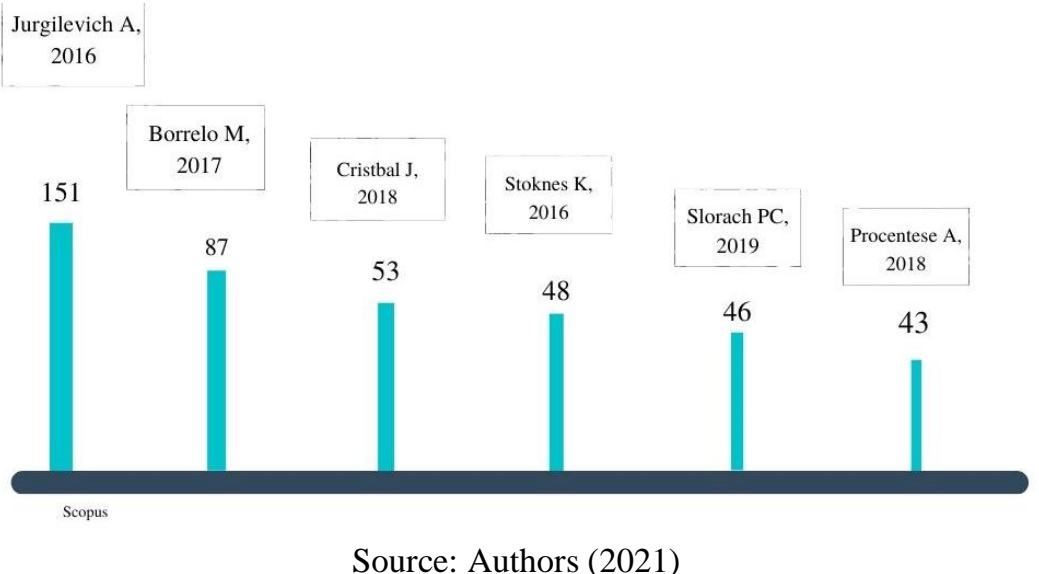

To analyze the amount of terms with greater mentions, it was produced a graph with the most cited key words in the WEB OF SCIENCE database for better understanding. Following the context elaborated, (Rodrigues, 2015), adds that Zipf's Law allows estimating the frequencies of occurrence of the words of a particular scientific and technological text, therefore the examined strand presents in total (07) distinct words with the amount of (88) words used, of which Food waste appear (19 times,) followed by the words Management (16), Life cycle assessment(13), Energy(12), Anaerobic digestion(11), system (9) and lastly Circular economy (8).

Graph 6: Most cited words Web of Science

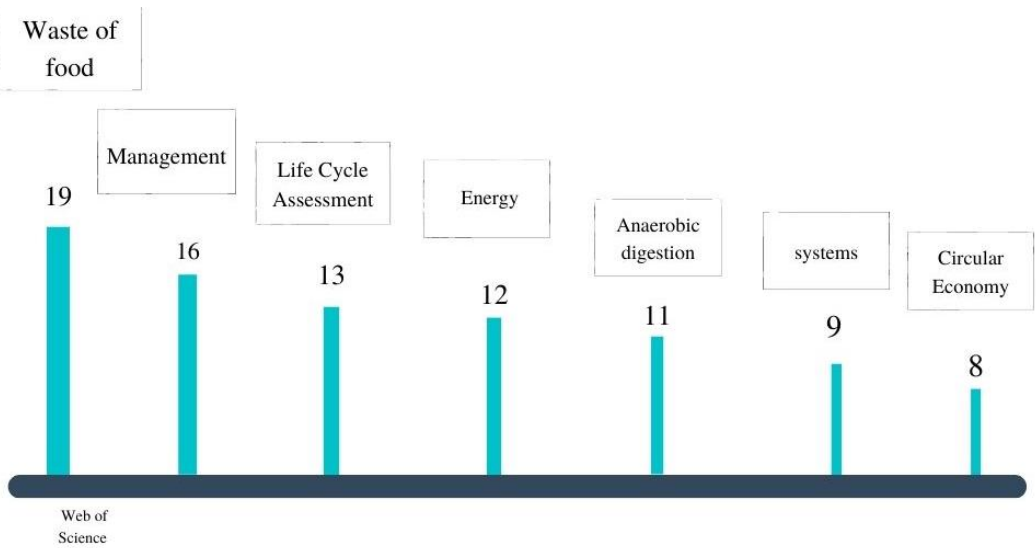

Source: Authors (2021)

The most used words in the Scopus database shows the thematic of the document, it was possible to notice that the amount of words cited was higher, presenting (248) words used with differentiation of 7 words, of which Food waste appears (70 times) followed by the words Waste management (41), Anaerobic digestion (33), Circular economy (28), Recycling (27), Article (25) and lastly Food (24).

Graph 7: Most cited Scopus words

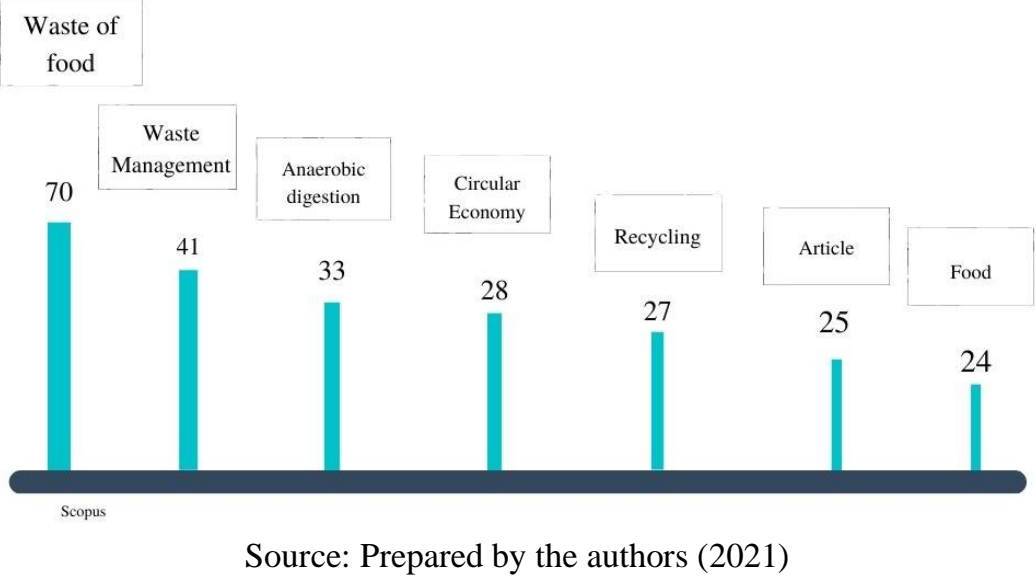


Although the Scopus database presents a greater number of words mentioned, the WEB OF SCIENCE database shows terms with greater links to the theme of the article. In addition, the fact that the word food waste appears in first place in both bases shows the timeliness of the theme presented.

Figure 5: Word cloud with the keywords that appear in the articles, Web of Science

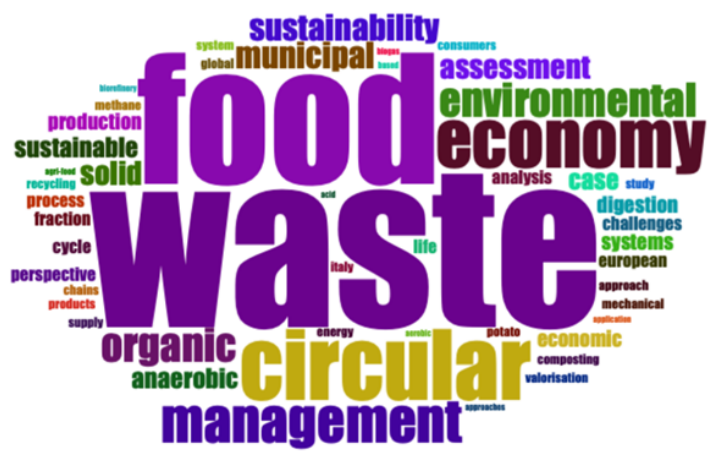

Source: Authors (2021)

The study of this information allows us to know the importance of the immersion of the key words in the circular economy context and how it can assist in reducing food waste. The most repeated terms are "Food" and "Waste", followed by the terms "Management", "Circular" and "Economy" with the 19 articles analysed. The analysis of the words shows that the authors decided to merge the data and knowledge for greater reliability in the results, showing that the concept of food waste is linked to various concepts, thus it is possible to base for further investigations of studies related to the theme of food waste and circular economy.

Figure 6: Word cloud with the keywords that appear in the articles, Scopus

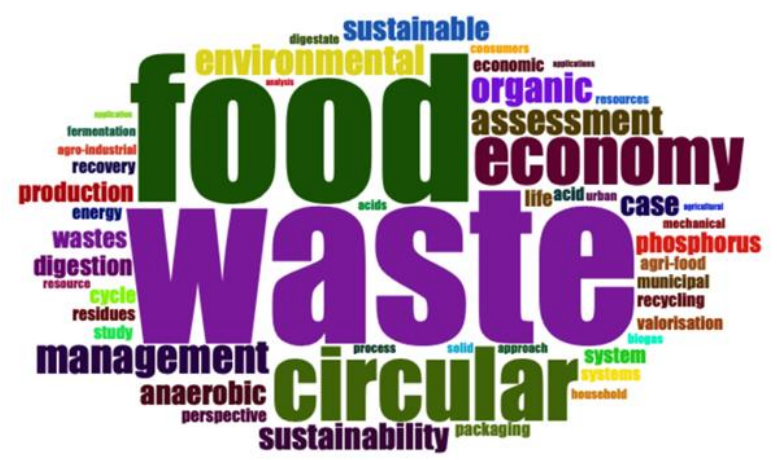

Source: Authors (2021)

In the Scopus database, the visual representation of key word data shows that there is not much difference with WEB OF SCIENCE, what distinguishes are the numbers of words with lower citations, such as "Agri-food" and "Valorisation" terms, showing that, regardless of the base, the words that guide the circular economy and food waste themes are equivalent.

\section{Analysis of the selected articles (19 articles): Step 2: (Analysis of the selected articles)}

After the overall evaluation of articles, the guiding question "How can the Circular Economy help reduce food waste?" was used to filter research that would be the object of further study, all titles, abstracts and future research were read. In the end, 19 articles were chosen to compose this systematic review. Thus, 86 studies were excluded for not having specific relationship with the guiding question.

Table 1 presents the data of the selected articles such as title, country of origin, number of authors, journal of publication and language. 
Table 1: Data from the Articles

\begin{tabular}{|c|c|c|c|c|}
\hline Auhors & Title & Country & $\begin{array}{l}\text { Total } \\
\text { Authors }\end{array}$ & Journal \\
\hline $\begin{array}{lll}\text { Secondi et al } \\
\text { (2019) }\end{array}$ & $\begin{array}{l}\text { Reusing Food Waste in Food Manufacturing Companies: The } \\
\text { Case of the Tomato-Sauce Supply Chain }\end{array}$ & Switzerland & 4 & $\begin{array}{l}\text { SUSTAINABILITY- } \\
\text { BASEL }\end{array}$ \\
\hline $\begin{array}{l}\text { McCarthy et al } \\
(2019)\end{array}$ & $\begin{array}{l}\text { Circular agri-food approaches: will consumers buy novel } \\
\text { products made from vegetable waste? }\end{array}$ & England & 3 & RURAL SOC \\
\hline Durrani (2019) & $\begin{array}{l}\text { Waste Management and Collaborative Recycling: An SDG } \\
\text { Analysis for a Circular Economy }\end{array}$ & Italy & 1 & EUR J SUSTAIN DEV \\
\hline Vinck et al (2019) & $\begin{array}{l}\text { Design opportunities for organic waste recycling in urban } \\
\text { restaurants }\end{array}$ & England & 3 & WASTE MANAGE RES \\
\hline $\begin{array}{l}\text { Rolewicz-Kalińska } \\
\text { et al (2020) }\end{array}$ & $\begin{array}{l}\text { The Circular Economy and Organic Fraction of Municipal } \\
\text { Solid Waste Recycling Strategies }\end{array}$ & Switzerland & 3 & ENERGIES \\
\hline Tonini et al (2020) & $\begin{array}{l}\text { Quantitative sustainability assessment of household food waste } \\
\text { management in the Amsterdam Metropolitan Area }\end{array}$ & Netherlands & 8 & $\begin{array}{l}\text { RESOUR CONSERV } \\
\text { RECY }\end{array}$ \\
\hline $\begin{array}{l}\text { Slorach et al } \\
(2020)\end{array}$ & $\begin{array}{l}\text { Environmental sustainability in the food-energy-water-health } \\
\text { nexus: A new methodology and an application to food waste in } \\
\text { a circular economy }\end{array}$ & $\begin{array}{l}\text { United } \\
\text { Kingdom }\end{array}$ & 4 & WASTE MANAGE \\
\hline Borrello et al, 2020 & $\begin{array}{l}\text { Consumers are willing to participate in circular business } \\
\text { models: A practice theory perspective to food provisioning }\end{array}$ & $\begin{array}{l}\text { United } \\
\text { Kingdom }\end{array}$ & 5 & J CLEAN PROD \\
\hline $\begin{array}{l}\text { Lehtokunnas et al } \\
(2020)\end{array}$ & $\begin{array}{l}\text { Towards a circular economy in food consumption: Food waste } \\
\text { reduction practices as ethical work }\end{array}$ & England & 4 & J CONSUM CULT \\
\hline Rivera et al (2020) & $\begin{array}{l}\text { Life cycle environmental sustainability of valorisation routes } \\
\text { for spent coffee grounds: From waste to resources }\end{array}$ & Netherlands & 4 & $\begin{array}{l}\text { RESOUR CONSERV } \\
\text { RECY }\end{array}$ \\
\hline $\begin{array}{l}\text { Fogarassy et al } \\
(2020)\end{array}$ & $\begin{array}{l}\text { Relations between Circular Economic Principles and Organic } \\
\text { Food Purchasing Behavior in Hungary }\end{array}$ & Switzerland & 5 & AGRONOMY-BASEL \\
\hline $\begin{array}{l}\text { Sadhukhan et al } \\
\text { (2020) }\end{array}$ & $\begin{array}{l}\text { Perspectives on Game Changer Global Challenges for } \\
\text { Sustainable } 21 \text { st Century: Plant-Based Diet, Unavoidable Food } \\
\text { Waste Biorefining, and Circular Economy }\end{array}$ & Switzerland & 7 & $\begin{array}{l}\text { SUSTAINABILITY- } \\
\text { BASEL }\end{array}$ \\
\hline $\begin{array}{l}\text { Erceg \& Margeta } \\
(2019)\end{array}$ & $\begin{array}{l}\text { Selection of food waste management option by promethee } \\
\text { method }\end{array}$ & Croatia & 2 & $\begin{array}{l}\text { ELECTRON J FAC CIV } \\
\text { E }\end{array}$ \\
\hline $\begin{array}{l}\text { Fassio \& Minotti } \\
(2019)\end{array}$ & $\begin{array}{l}\text { Circular Economy for Food Policy: The Case of the RePoPP } \\
\text { Project in The City of Turin (Italy) }\end{array}$ & Switzerland & 2 & $\begin{array}{l}\text { SUSTAINABILITY- } \\
\text { BASEL }\end{array}$ \\
\hline Laso et al (2018) & $\begin{array}{l}\text { Combined application of Life Cycle Assessment and linear } \\
\text { programming to evaluate food waste-to-food strategies: } \\
\begin{array}{l}\text { Seeking } \\
\text { nexus approach }\end{array}\end{array}$ & Spain & 11 & $\begin{array}{l}\text { ENVIRON SCI } \\
\text { TECHNOL }\end{array}$ \\
\hline $\begin{array}{l}\text { Borrello et al } \\
\text { (2017) }\end{array}$ & $\begin{array}{lcll}\text { Consumers' Perspective on } & \text { Circular } & \text { Economy } \\
\text { Strategy for Reducing Food Waste } & & \end{array}$ & Italy & 5 & WASTE MANAGE \\
\hline Mylan et al (2016) & $\begin{array}{l}\text { Re-Introducing Consumption to the 'Circular } \\
\text { Economy': A Sociotechnical Analysis of Domestic } \\
\text { Food Provisioning }\end{array}$ & England & 3 & WASTE MANAGE \\
\hline Cobo et al (2018) & $\begin{array}{l}\text { Trade-offs between nutrient circularity and environmental } \\
\text { impacts in the management of organic waste }\end{array}$ & Spain & 3 & $\begin{array}{l}\text { SUSTAINABILITY- } \\
\text { BASEL }\end{array}$ \\
\hline $\begin{array}{l}\text { Pérez-Camacho et } \\
\text { al (2018) }\end{array}$ & $\begin{array}{l}\text { Life cycle environmental impacts of substituting food wastes } \\
\text { for traditional anaerobic digestion feedstocks }\end{array}$ & $\begin{array}{l}\text { United } \\
\text { Kingdom }\end{array}$ & 3 & $\begin{array}{l}\text { SUSTAINABILITY- } \\
\text { BASEL }\end{array}$ \\
\hline
\end{tabular}

Source: the authors (2021).

The literature presents performances in several countries. Considering the filters and guidelines applied in the project that were: the keywords chosen in the search, as well as the numbers of articles in full text evaluated for eligibility that had a total of 19 projects, besides the consideration of the exclusion of articles with original language other than English, Spanish and Portuguese. Detain in terms of regions predominance in different European countries, with quantity and percentage: 1 in Croatia (5.26\%), 2 in Spain (10.52\%), 2 in the Netherlands (10.25\%), 4 in England (21.05\%),2 in Italy (10.52\%), 3 in the United Kingdom (15.78\%) and finally 5 articles in Switzerland (26.31\%).

In addition, in relation to the languages found through the filters applied, the English language was originally obtained, reaching a quantity and percentage: 19 articles (100\%) use English language (see 
Table 2). As shown in Table 2, Switzerland was the top country that published articles on the topic addressed in this study, with 5 articles published out of 19.

Table 2: Number of Published Articles, Country of Publication and Language

\begin{tabular}{l|c|c}
\multicolumn{1}{c|}{ Country } & Publication Language & Articles \\
\hline Croatia & English & 1 \\
\hline Spain & English & 2 \\
\hline Netherlands & English & 2 \\
\hline England & English & 4 \\
\hline Italy & English & 2 \\
\hline United Kingdom & English & 3 \\
\hline Switzerland & English & 5 \\
\hline
\end{tabular}

Source: the authors (2021).

Regarding the number of authors for the preparation of articles, it can be observed that, in general, the number of authors varies from 3 to 4 (see Graph 8). It is important to pay attention to this fact due to the limited number required by the journals.

Graph 8: Number of Authors per Article

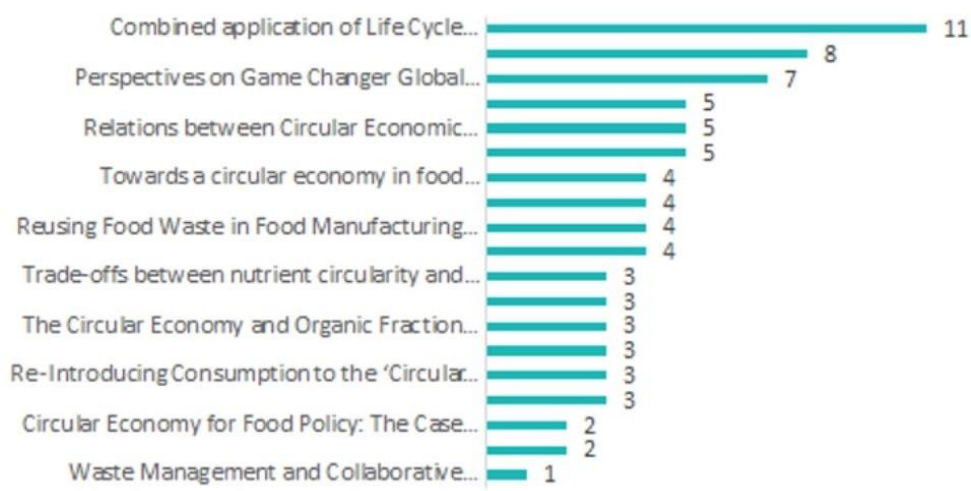

Source: the authors (2021).

Amongst the journals where articles were published, one can see that Sustainability-Basel journal had a predominance of publication on the theme, with 5 publications amongst elected articles. Followed by the journal Waste Manage, with 3 publications (see Graph 9).

Graph 9: Relationship between Journals and Published Articles

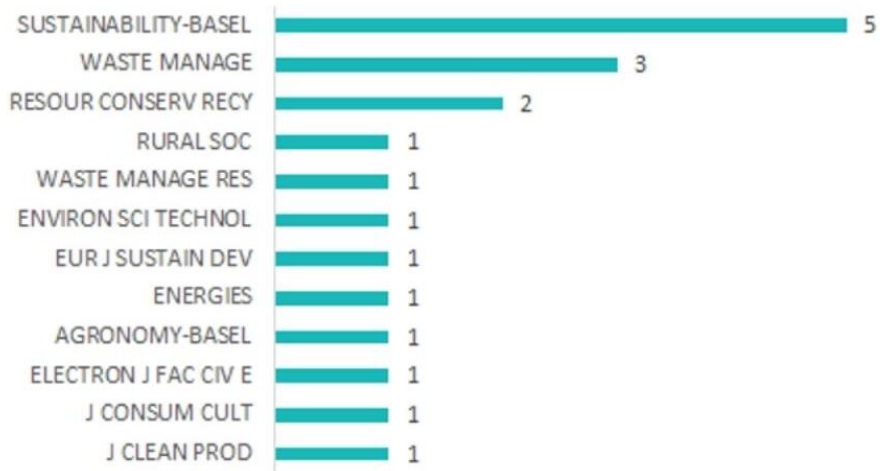

Source: the authors (2021). 
Considering Figure 7, which presents the cloud of keywords of the articles, one can analyze the diversity of keywords, but with predominance of the words "Circular Economy", "Design for sustainability", "Organic food waste" and "Biogas production".

Figure 7: Keyword Cloud

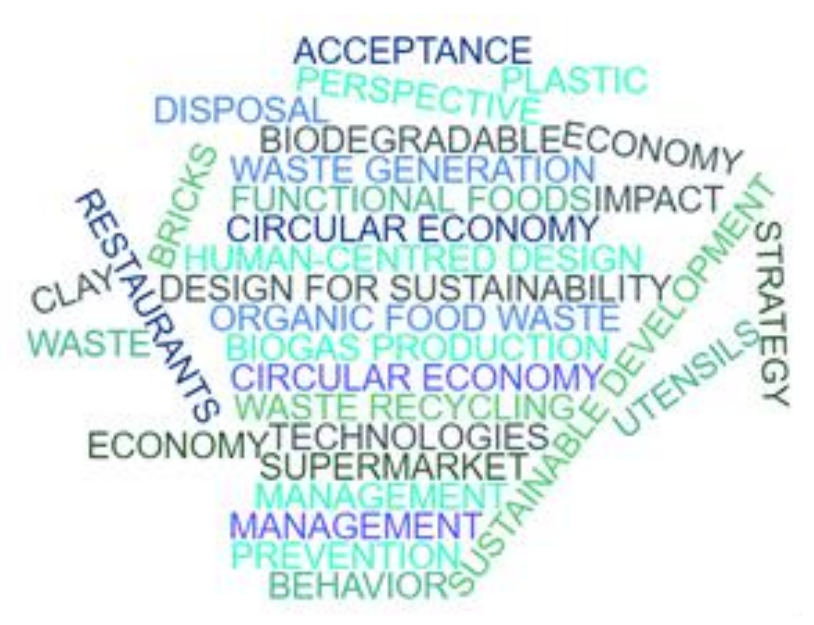

Source: the authors (2021).

With regard to the authors with more publications, it is possible to verify the influence of the author Caracciolo, F., being this centralized and highlighted in the Authors' Cloud of Words (see Figure 8).

Figure 8: Authors' Cloud of Words

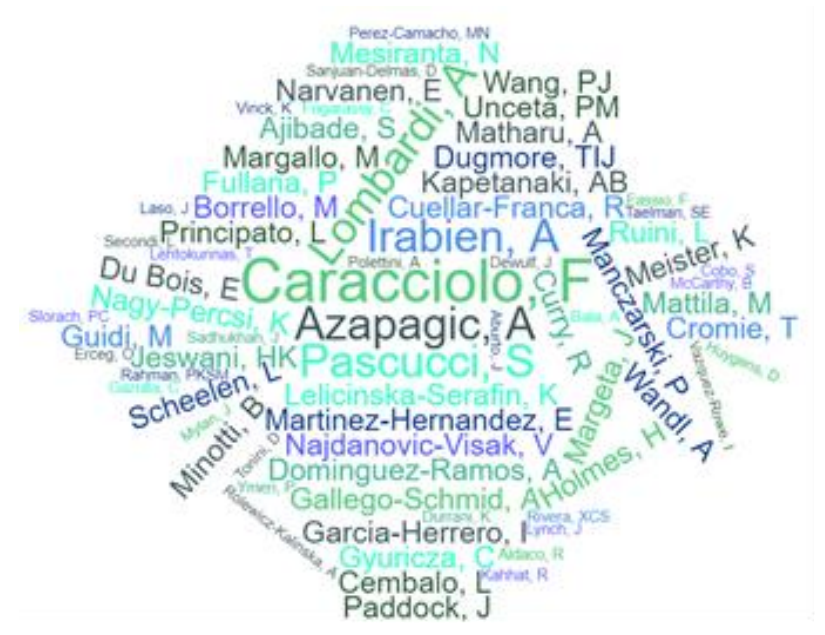

Source: the authors (2021).

Table 3 shows the GAPs that were expressed in the selected articles. The GAP identification is an essential step to verify the gap on a given theme in the articles and information present around the world. The GAP can verify unsolved problems, restrictions of preliminary studies and issues that have not yet been considered by authors.

Table 3: GAPs of the Articles

\begin{tabular}{c|l}
\multicolumn{1}{c|}{ Auhors } & GAP \\
\hline Secondi et al (2019) & $\begin{array}{l}\text { Focused on quantifying the FLW generated in the tomato sauce industry, from cultivation to retail. To our } \\
\text { knowledge, there are no previous studies that have considered the amount of total FLW generated during } \\
\text { this specific FSC. In fact, existing studies have focused more on emissions at specific FSC stages, probably } \\
\text { due to the "lack of reliable and accessible information on waste from some stages but not others" }\end{array}$ \\
\hline McCarthy et al (2019) & $\begin{array}{l}\text { Unlike other circular economy studies, which tend to focus on industrial processes and activities, such as } \\
\text { design for disassembly and recycling, this research focused on the consumer perspective, contributing to the } \\
\text { small but growing literature that advocates a more nuanced perspective on the circular economy }\end{array}$
\end{tabular}


\begin{tabular}{|l|l} 
Durrani (2019) & Besides monetary considerations, the waste covered in a landfill is sorted at an exceptionally moderate rate
\end{tabular} and remains an unpredictable problem for humanity.Another challenge would be that, despite the various possible focal points from building an attractive recycling process, experience has demonstrated some obstructions that deny the enhancement of powerful recycling markets

\begin{tabular}{|c|c|}
\hline Vinck et al (2019) & $\begin{array}{l}\text { Despite being in evolution towards a circular economy, over } 61 \% \text { of restaurants do not collect organic waste } \\
\text { separately from waste. In the research, this problem was explored from a human-centered perspective by } \\
\text { analyzing existing food waste collection and processing equipment and observing the kitchen workflow and } \\
\text { interior design of different localized urban restaurants. }\end{array}$ \\
\hline $\begin{array}{l}\text { Rolewicz-Kalińska et al } \\
\text { (2020) }\end{array}$ & $\begin{array}{l}\text { Analysing the link between bio-waste collection and circular economy requirements such as meeting } \\
\text { recycling rates and using biogas as a sustainable energy source. Showing the significant need to develop } \\
\text { more effective separate collection systems including bio-waste. }\end{array}$ \\
\hline Tonini et al (2020) & $\begin{array}{l}\text { Food waste represents the largest fraction of municipal solid waste generated in Europe and its management } \\
\text { is associated with sub-optimal performance in environmental, health and social dimensions. Aiming to } \\
\text { quantify the environmental and socio-economic impacts of household food waste management in the } \\
\text { Amsterdam Metropolitan Area based on priorities defined by local stakeholders. }\end{array}$ \\
\hline Slorach et al (2020) & $\begin{array}{l}\text { Presents a new methodology for assessing environmental sustainability at the food-energy-water-health } \\
\text { nexus on a life cycle basis. }\end{array}$ \\
\hline Borrello et al, 2020 & $\begin{array}{l}\text { Analyzes consumer participation in circular business models and consumer willingness to participate in an } \\
\text { innovative food sourcing mechanism with retailers. }\end{array}$ \\
\hline Lehtokunnas et al (2020) & $\begin{array}{l}\text { Transition to a circular economy in the context of household food waste practices. The transition to a circular } \\
\text { economy requires, in addition to new technologies, infrastructure, and innovations, societal change and a } \\
\text { shift in everyday practices }\end{array}$ \\
\hline Rivera et al (2020) & $\begin{array}{l}\text { Evaluates the life cycle environmental impacts of using SCGs for biodiesel production compared to the } \\
\text { widely used disposal of SCGs as a waste stream: incineration, landfill, anaerobic digestion, composting and } \\
\text { direct land application. }\end{array}$ \\
\hline Fogarassy et al (2020) & $\begin{array}{l}\text { To explore the circular characteristics of consumers' attitude towards food purchasing in Hungary. Factor } \\
\text { and cluster analyses were applied for market segmentation. }\end{array}$ \\
\hline Sadhukhan et al (2020) & $\begin{array}{l}\text { Multi-disciplinary approaches spanning chemistry, process engineering and sustainability science, and } \\
\text { sustainable solutions in "revolutionary" challenges in three intersecting food arenas: sustainable diet, } \\
\text { valorization of unavoidable food supply chain waste and circularity of the food value chain UN-aligned } \\
\text { systems }\end{array}$ \\
\hline Erceg \& Margeta (2019) & Identifying food waste treatment for small islands is discharging food waste in the city \\
\hline Fassio \& Minotti (2019) & $\begin{array}{l}\text { The circular economy for food (CE) and food policy (FP) are two emerging research areas, with the intention } \\
\text { of analysing the dynamics between these two research fields, based on review articles and the analysis of a } \\
\text { case study }\end{array}$ \\
\hline Laso et al (2018) & $\begin{array}{l}\text { The major concern of food loss (FL) has been studied before, but in an isolated way, disregarding } \\
\text { interdependencies with other areas. This paper intends to take a step forward, proposing a new procedure to } \\
\text { evaluate different waste management alternatives based on the nexus approach through an integrated Water- } \\
\text { Energy-Food-Climate Nexus Index (WEFCNI) }\end{array}$ \\
\hline Borrello et al (2017) & $\begin{array}{l}\text { Role of new technologies to assess consumers' willingness to actively engage in closed loops aimed at } \\
\text { reducing food waste. }\end{array}$ \\
\hline Mylan et al (2016) & $\begin{array}{l}\text { The paper makes two contributions to advancing the 'circular economy' as a blueprint for a more sustainable } \\
\text { society. The first is to highlight the importance of understanding the dynamics of consumption and waste in } \\
\text { the domestic sphere. The second is to illustrate two ways that using insights from the sociotechnical literature } \\
\text { on sustainable consumption, in combination with the sociology of food, could contribute to redressing this } \\
\text { deficiency. }\end{array}$ \\
\hline Cobo et al (2018) & $\begin{array}{l}\text { Propose an indicator that quantifies the effectiveness of a system by extending the life of its waste } \\
\text { components after they have been discarded }\end{array}$ \\
\hline Pérez-Camacho et al (2018) & $\begin{array}{l}\text { Life cycle assessment was used to evaluate the life cycle environmental impacts of substituting feedstocks } \\
\text { for traditional anaerobic digestion (DA) with food waste. }\end{array}$ \\
\hline
\end{tabular}

Source: the authors (2021).

Future suggestions have the ability to direct and expand future studies on the subject addressed. This is a crucial issue to assist and guide the next researchers to add a particular theme. Table 4 denotes the future suggestions addressed in the articles. 
Table 4: Future Suggestions

\begin{tabular}{|c|c|}
\hline Authors & Future Suggestions \\
\hline Secondi et al (2019) & $\begin{array}{l}\text { Finally, future research can add knowledge on other supply chains in order to impose, adapt and refine the } \\
\text { methodologies used to quantify FLWs, thus providing effective pictures of this phenomenon. These } \\
\text { contributions can help reduce losses and waste across the FSC and give the chance for food companies to be a } \\
\text { major enabler of UN SDG number } 12.3\end{array}$ \\
\hline McCarthy et al (2019) & $\begin{array}{l}\text { The findings associating willingness to purchase value-added food and consumers' awareness of the food waste } \\
\text { problem found correlation, yet, future research could be conducted to test whether a causal relationship exists } \\
\text { using other methods or statistical tests. }\end{array}$ \\
\hline Durrani (2019) & $\begin{array}{l}\text { In particular, mindfulness projects should be targeted to enhance learning about the importance of SWM for } \\
\text { ecologically sound advancement in the zone. The experts should accommodate the presentation of the } \\
\text { complementary projects, as mentioned earlier, and address the improvement. The ardent objective is to create } \\
\text { a sustainable environment through equitable solutions and enforcement to ensure a better future for relatives. }\end{array}$ \\
\hline Vinck et al (2019) & $\begin{array}{l}\text { Conclusions and generalizations from the research should be made considering the limitations of the } \\
\text { methodology applied. Future research should consider the use of video or other devices for contextual } \\
\text { immersion to alleviate some of the limitations of a single visit. This would allow the development of a graphical } \\
\text { flowchart associating waste generation, personnel flow, relative amounts of food and waste, and connected } \\
\text { spaces. In addition, more extended surveys with participants (including administrative, kitchen, lounge and } \\
\text { dishwasher staff) during observations and interviews would allow for further optimization and detailing of } \\
\text { these findings. }\end{array}$ \\
\hline Rolewicz-Kalińska et al (2020) & $\begin{array}{l}\text { In future work, the analysis should be extended to variable factors related also to packaging and textile waste. } \\
\text { In addition, the issue of the processing economics of OFMSW should be developed, as it is a necessary factor } \\
\text { to implement the technology at full industrial scale. }\end{array}$ \\
\hline Tonini et al (2020) & $\begin{array}{l}\text { The results serve as a basis for prioritising sustainable solutions in the future waste and circular economy } \\
\text { strategy specifically for Amsterdam, but may also be useful in other European areas with similar } \\
\text { characteristics. }\end{array}$ \\
\hline Slorach et al (2020) & $\begin{array}{l}\text { The proposed methodology can be used to guide companies and policy makers in interpreting a wide range of } \\
\text { product environmental impacts, }\end{array}$ \\
\hline Borrello et al, 2020 & $\begin{array}{l}\text { Recommendations can be derived for future studies on the relevance of practice theory in the analysis of } \\
\text { consumer engagement in circular business models. }\end{array}$ \\
\hline Lehtokunnas et al (2020) & $\begin{array}{l}\text { The EC literature currently lacks in-depth knowledge about consumer culture, which provides consumer } \\
\text { researchers with an opportunity for cross-fertilization, following the path laid out by this study. }\end{array}$ \\
\hline Rivera et al (2020) & $\begin{array}{l}\text { It is also recommended to assess the economic and social implications of the options under analysis to provide } \\
\text { a comprehensive set of decision indicators to assist in the selection of the most sustainable alternative, and to } \\
\text { explore a range of functional units, congruent with the related objective and scope of the study, to assess the } \\
\text { effect on outcomes. }\end{array}$ \\
\hline Fogarassy et al (2020) & $\begin{array}{l}\text { For future research it is suggested to find the appropriate marketing tools, whose help can be integrated into } \\
\text { the systems, committing to the concept of EC. }\end{array}$ \\
\hline Sadhukhan et al (2020) & $\begin{array}{l}\text { It would help the research community to access feasible avenues for functionalization of a given food } \\
\text { ingredient } \\
\text { by means of a computer software product. }\end{array}$ \\
\hline Erceg \& Margeta (2019) & $\begin{array}{l}\text { The method is sensitive to analysis and has proven especially useful for choosing solutions and can be used } \\
\text { elsewhere. }\end{array}$ \\
\hline Fassio \& Minotti (2019) & $\begin{array}{l}\text { Further research should therefore focus not only on the design of new projects, such as RePoPP, but also on } \\
\text { the monitoring of current best practices. In order to encourage cities and academics to work with the EC } \\
\text { worldview and indicators, applying system design thinking and circularity to all future food policies. }\end{array}$ \\
\hline Laso et al (2018) & $\begin{array}{l}\text { Research is needed to ensure that the environmental impact of the circular economy works towards } \\
\text { sustainability. }\end{array}$ \\
\hline Borrello et al (2017) & Future studies should include the results of a Hierarchical Bayes model in order to investigate possible \\
\hline Mylan et al (2016) & $\begin{array}{l}\text { The authors do not specifically put a line on future research, they only reinforce their findings, which are. The } \\
\text { first is a shift from conceptualizing consumers as 'users' of particular products and services to imagining them } \\
\text { as 'doers' of particular activities during which resources are consumed. The second suggestion is a broadening } \\
\text { of the principle of 'eco-effectiveness' that underpins the design propositions to enact the 'circular economy'. }\end{array}$ \\
\hline Cobo et al (2018) & The article does not clearly address future research. \\
\hline Pérez-Camacho et al (2018) & $\begin{array}{l}\text { Research to develop guidelines for the design and evaluation of biogas / environmental bioenergy systems, } \\
\text { which includes: Feedstock transport distances; and avoided waste / resource management impacts. Research } \\
\text { into digestate utilization pathways and integrated / feedstock / bioenergy / biomaterial flow systems analysis } \\
\text { using the emerging anaerobic Biorefinery concept (Curry et al. (2017)); and research into synergies between } \\
\text { feedstocks for AD and feedstocks for other bioeconomy processes, including gasification / pyrolysis, } \\
\text { fermentation and algae. }\end{array}$ \\
\hline
\end{tabular}

Source: the authors (2021). 


\section{DISCUSSION}

The author (McCarthy et al, 2019) focuses on the consumer and incorporation function of transforming waste for reuse in accordance with the circular economy, arguing a more nuanced perspective on the circular economy. In contrast, the author (Sadhukhan et al, 2020) argues that the circular economy can be applied from new materials through techniques for the functionalization of plant-based proteins for food effects, using "regenerative bio-surfactants from unavoidable food waste .". As the author adds (Sadhukhan et al, 2020) "There are a multitude of biorefinery products and configurations that need to be considered and optimized using smart decision-making tools"

The authors (Sadhukhan, 2020), (Fassio \& Minotti, 2019) and (Secondi et al, 2019) bring the perspective of the importance of transforming a linear model to a circular model. Over the past 150 years, the world economy has been based on the linear process that results in products that become waste at the end of their life and which has proven to be no longer sustainable from both an economic, environmental and social point of view (Sencondi et al, 2019; McCarthy et al., 2019). The most common way in which products are managed entails a linear economy that discards resources that could be recovered and creates negative environmental and social impacts (Sadhukhan, 2020).

$\mathrm{CE}$ is in fact an alternative model based on the assumption that a change from a linear "produce, use and dispose" economy to a circular and regenerative one that dialogues with nature and is necessary to ensure a breakthrough in a sustainable economy (Fassio \& Minotti , 2019)

One of the goals of the circular economy in combating food waste is to reduce consumption. Mylan, Holmes \& Paddock (2016) argue that this effort is collective, made by the entire civil society. Elucidating that consumption patterns can be changed and adapted to a more sustainable practice, removing retrograde ideas and conceptualizing a more rational demand. Borrello et al (2017), collaborates with the consequences of this unrestrained consumption, in addition to bringing some contributions to the improvement of this scenario, such as the composting process, a method of aerobic decomposition of organic matter made by bacteria, fungi, insects and earthworms; with the purpose of reducing the environmental impact, created by consumerism and the unbridled production of the great world metropolises.

Consumption patterns are a consequence of massive production from the Second World War onwards, a consequence of material infrastructure and technologies that contributed to this culture that is seen as normal and desirable. These behaviors are influenced in everyday life processes, being replicated and followed collectively, that is, consumption is more social than individual, hence the importance of understanding consumption patterns and how they are supported, to outline alternatives that seek to make the population aware of the danger of abusive consumption, unnecessary purchases and their eventual disposal (Mylan, Holmes \& Paddock, 2016).

It can be pointed out that the prospects for implementing the circular economy exist due to a global need to reduce consumerism, climate change, land and sea degradation and provide a sustainable environment. The urgency of drawing up strategies is essential for the survival of the planet and the beings that inhabit it. Changes in society's way of life need to be reviewed and readjusted, towards a circular value chain (Lehtokunnas et al., 2020).

Fogarassy et al. (2020) explores the attitude of consumers and their connection with the behavior of buyers and their possible contributions to food waste. His analysis found that highly educated young people are more aware and can be targets for circular innovation, but it highlights the social inequality in access to information and education that can put disadvantaged individuals on the path of integrating more sustainable measures and less food waste.

The authors (Lehtokunnas et al., 2020) and (Rivera et al., 2020) address in their texts one of the main strategies of the circular economy to reduce food waste, the elaboration of a life cycle for materials or food. Food residues directly affect sustainability and planetary balance, in addition to the economic 
and social meaning that these measures can add for a better circular management of these products. Lehtokunnas et al. (2020), brings a contribution about a junction between circular economy and a moral economy. It aims to measure responsibilities and possibilities in the performance of an entire civil society and any moral problematization of practices seen as unsustainable in the logic of a circular economy.

Rivera et al (2020) specifically addresses the coffee powder and its best use in a closed life cycle circuit after its use and disposal. The reused product has the ability to generate added value, being reintegrated into the bioeconomy as a raw material for the production of biodiesel. Their studies show a negative GHG production, analyzing the management methods used with the intention of understanding and dealing with the taxes that this process can entail, such as incineration, landfill, anaerobic digestion, composting and direct application to the soil.

Adopting a Circular Economy can be implemented in restaurants through selective collection and has enormous potential for economic, social and ecological improvements (Vink et al., 2019).

The authors (Borrello et al., 2017) and (Fassio \& Minotti, 2019) highlight in their texts the relevance of adopting a Circular Economy system in favor of sustainability. Borrello et al. (2017) states that CE strategies are extremely important to reestablish the model of producing, consuming and discarding, through the active participation of all actors in the production chains. Fassio \& Minotti (2019) transcribe that CE strategies can help in developing the understanding of the entire food system, in refining the ability to understand its parts, in verifying the fundamental and necessary interconnections to challenge the future and in the contemplation of creativity for the redesign of the production system.

Circular Economy tries to design closed circuits of resources with the objective of eliminating waste and reducing the impacts of human actions on the environment. To achieve this proposal, the EC makes use of the basic practice of recycling materials inserted in natural ecosystems and known as 3Rs. In the linear economy, consumers are the last link in supply chains. Their participation is limited to the mere purchase of products (Borrello et al., 2017). Lehtokunnas et al (2020), states that the production of food waste is significantly affecting the sustainability of the food system and that CE is seen as an alternative to the linear economic model characterized by producing, consuming and discarding the product. Both authors agree on the importance of adopting CE to combat unsustainability and that closed cycles are capable of reducing this food waste.

\section{CONCLUSIONS}

The article contributes to clarifying and debating the Circular Economy, with the aim of verifying how the transition from a linear model of the economy to a circular model can help to reduce food waste.

When performing a systematic review analysis of the articles globally, it is noted a significant growth in published articles between the years 2016 and 2020. In the period prior to 2016, there was no return of articles with the chosen keywords, Economy circular and food waste, showing the recent search for the theme. Among the 275 articles in the Scopus Base and the 275 articles in the Web of Science Base, the keywords most covered were "Waste" and "Food", which are relevant in the elaboration of studies in this area. Among the chosen articles, Europe had the greatest predominance in the discussion of this approach, with 12 articles published among the 19, with 5 of these articles having Switzerland as origin country.

Regarding the journal with the most publications on the subject, Sustainability-Basel had the highest number of publications, concentrating 5 articles by the chosen ones. When carrying out an in-depth analysis of the selected articles, it was noticed that the subject addressed in this research is recent, but has great strength for significant changes in the approach to sustainability. 
The Circular Economy envisions reducing waste, making the environment more sustainable (Borrello et al., 2017; Fassio \& Minotti, 2019; Fogarassy et al., 2020; Lehtokunnas et al., 2020; McCarthy et al., 2019; Mylan, Holmes; \& Paddock, 2016) transforming the linear model into a cycle that replaces products that would be discarded again in the economy (Borrello et al., 2017; Sadhukhan, 2020; Fassio \& Minotti, 2019).

The implementation of the Circular Economy aimed to bring about changes in the social, economic and environmental spheres by reducing consumerism, improving climate aspects, minimizing the degradation of soils and seas and providing a more sustainable environment (Fogarassy et al., 2020; Rivera et al., al., 2020; Lehtokunnas et al., 2020; Vink et al., 2019). Studies show the efficiency of adopting a circular model to face challenges and support countries to reduce the amount of waste produced (Borrello et al., 2020; Durrani, 2019; Lehtokunnas et al., 2020).

When analyzing the methodology used by the authors, the vast majority was classified as bibliographic research. Among the methods used by the authors, one can also find the qualitative one through the application of a questionnaire and the qualitative one, where interviews with interest groups were carried out. The limitations of systematic review, despite the commitment and relevance of the articles and selected academic research bases, only open access articles were used, so it is suggested to expand the research discussion in other databases and also provide partnerships to reach articles closed, in order to obtain other lines of research and data.

Analyzing the 19 articles proposed in this systematic review, it was found that researched measures and elaborated actions, in the search for a more sustainable path between economy and environment. In addition to public policies aimed at a closed circuit, advocated by the Circular Economy, they are being debated and implemented.

The main focus is to avoid a global collapse, provoked by the unrestrained increase in production and consumption since the industrial revolution, intensified in the middle of the 20th century. That culminated in the degradation of the soil, seas and the consequent air pollution caused by all these factors, and in the social issue, the increase in social inequality between countries and people, and the evolution of food insecurity, especially among the most vulnerable.

Based on the diagnosis made, this article suggests, as future research, a greater connection between circular economy and food insecurity, through food waste. The articles investigated focus mainly on food waste for the production of raw materials, in energy production, biofuels for example; or emphasize awareness of a better way to use food or even reduce its consumption. However, products that will not be used due to possible damage to the packaging or to the food itself, but which are suitable for consumption. We believe that Circular Economy is an important expertise to reflect on this problem, aggravated by the current global scenario, the Covid-19 Pandemic.

\section{REFERENCES}

Abiad, M. G., \& Meho, L. I. (2018). Food loss and food waste research in the Arab world: A systematic review. Food security, 10(2), 311-322. https://doi.org/10.1007/s12571-018-0782-7

Boloy, R. A. M., Reis, A.C., Rios, E. M., Martins, J. A. S., Soares, L. O., Sá Machado, V. A., \& Moraes, D. R. (2021). Waste-to-Energy Technologies Towards Circular Economy: a Systematic Literature Review and Bibliometric Analysis. Water, Air, \& Soil Pollution, 232(7), 1-25. https://doi.org/10.1007/s11270-021-05224-X

Borrello, M., Caracciolo, F., Lombardi, A., Pascucci, S., \& Cembalo, L. (2017). Consumers' perspective on circular economy strategy for reducing food waste. Sustainability, 9(1), 141. https://doi.org/10.3390/su9010141

Borrello, M., Pascucci, S., Caracciolo, F., Lombardi, A., \& Cembalo, L. (2020). Consumers are willing to participate in circular business models: A practice theory perspective to food provisioning. Journal of Cleaner Production, $259,121013$. https://doi.org/10.1016/j.jclepro.2020.121013 
Cobo, S., Dominguez-Ramos, A., \& Irabien, A. (2018). Trade-offs between nutrient circularity and environmental impacts in the management of organic waste. Environmental science \& technology, 52(19), 10923-10933. https://doi.org/10.1021/acs.est.8b01590

Concolato, C. de O. F., Cunha, M. R., \& Afonso, H. C. A. da G. (2020). Economic feasibility for photovoltaic solar energy projects: a systematic review. Revista Produção e Desenvolvimento, 6. https://doi.org/10.32358/rpd.2020.v6.506

Cruz, V. P. S., \& Araujo, F. O. (2021). Relationship between project governance, project portfolio and best practices in an energy transmission company. Revista Produção e Desenvolvimento, 7. https://doi.org/10.32358/rpd.2021.v7.571

Donato, H., \& Donato, M. (2019). Etapas na Condução de uma Revisão Sistemática. Acta Médica Portuguesa, 32(3). https://doi.org/10.20344/amp.11923

Durrani, K. (2019). Waste Management and Collaborative Recycling: An SDG Analysis for a Circular Economy. European Journal of Sustainable Development, 8(5), 197-197. https://doi.org/10.14207/ejsd.2019.v8n5p197

ELLEN MACARTHUR FOUNDATION Towards the Circular Economy: Economic and business rationale for an accelerated transition. Acessado em: https://www.ellenmacarthurfoundation.org/assets/downloads/publications/EllenMacArthur-Foundation-Towards-the-Circular-Economy-vol.1.pdf , 2013.

Erceg, O., \& Margeta, J. (2019). Selection of food waste management option by promethee method. Electronic Journal of the Faculty of Civil Engineering Osijek-e-GFOS, 10(19), 87-97. https://doi.org/10.13167/2019.19.9

FAO (2019). The state of food and agriculture. Recuperado em maio, 27, 2021 em http://www.fao.org/3/ca6030en/ca6030en.pdf

FAO (2021). Food Loss and Food Waste. Recuperado em maio, 27, 2021 em http://www.fao.org/food-loss-and-foodwaste/flw-data

Fassio, F; \& Minotti, B. (2019). Circular Economy for Food Policy: The Case of the RePoPP Project in The City of Turin (Italy). Sustainability 11(21), 6078. https://doi.org/10.3390/su11216078

Fogarassy, C., Nagy-Pércsi, K., Ajibade, S., Gyuricza, C., \& Ymeri, P. (2020). Relations between circular economic "principles" and organic food purchasing behavior in Hungary. Agronomy, $10(5), 616$. https://doi.org/10.3390/agronomy10050616

Galvão, M. C. B., \& Ricarte, I. L. M. (2019). Revisão sistemática da literatura: conceituação, produção e publicação. Logeion: Filosofia da informação, 6(1), 57-73. https://doi.org/10.21728/logeion.2019v6n1.p57-73

Germano, A. X. D. S., Mello, J. A. V. B., \& Motta, W. H. (2021). Contribuição das tecnologias da indústria 4.0 para a sustentabilidade: uma revisão sistemática. Palabra Clave (La Plata), 11(1), e142. https://doi.org/10.24215/18539912e142

Jurgilevich, A., Birge, T., Kentala-Lehtonen, J., Korhonen-Kurki, K., Pietikäinen, J., Saikku, L., \& Schösler, H. (2016). Transition towards circular economy in the food system. Sustainability, 8(1), 69. https://doi.org/10.3390/su8010069

Kirchherr, J., Reike, D., \& Hekkert, M. (2017). Conceptualizing the circular economy: An analysis of 114 definitions. Resources, conservation and recycling, 127, 221-232. https://doi.org/10.1016/j.resconrec.2017.09.005

Kokol, P., Blažun Vošner, H., \& Završnik, J. (2020). Application of bibliometrics in medicine: A historical bibliometrics analysis. Health Information \& Libraries Journal, 38(2), 125-138. https://doi.org/10.1111/hir.12295

Lalrempuii, S., Ngurtinkhuma, R. K., \& Mishra, R. N. (2020). Application of Bibliometric Laws in Doctoral Theses of Library and Information Science in the Universities of North East India. Journal of Indian Library Association, 55(4), 4758.

Laso, J., Margallo, M., García-Herrero, I., Fullana, P., Bala, A., Gazulla, C., ... \& Aldaco, R. (2018). Combined application of Life Cycle Assessment and linear programming to evaluate food waste-to-food strategies: Seeking for answers in the nexus approach. Waste Management, 80, 186-197. https://doi.org/10.1016/j.wasman.2018.09.009

Lehtokunnas, T., Mattila, M., Närvänen, E., \& Mesiranta, N. (2020). Towards a circular economy in food consumption: Food waste reduction practices as ethical work. Journal of Consumer Culture, 1469540520926252. https://doi.org/10.1177/1469540520926252

Mathankar, A. R. (2018). Bibliometrics: An overview. International Journal of Library \& Information Science (IJLIS), 7(3). https://doi.org/10.34218/IJLIS.7.3.2018.002

McCarthy, B; Kapenataki, A.; Wang, P. (2019). Circular agri-food approaches: will consumers buy novel products made from vegetable waste? Rural Society, 28(2), 91-107. https://doi.org/10.1080/10371656.2019.1656394

Mylan, J., Holmes, H., \& Paddock, J. (2016). Re-introducing consumption to the 'circular economy': A sociotechnical analysis of domestic food provisioning. Sustainability, 8(8), 794. https://doi.org/10.3390/su8080794 
Pérez-Camacho, M. N., Curry, R., \& Cromie, T. (2018). Life cycle environmental impacts of substituting food wastes for traditional anaerobic digestion feedstocks. Waste Management, 73, 140-155. https://doi.org/10.1016/j.wasman.2017.12.023

Potting, J., M.P. Hekkert, E. Worrell and A. Hanemaaijer. Circular Economy: Measuring innovation in product chains (Report 2544). PBL Netherlands Environmental Assessment Agency, the Hague, the Netherlands, 2016.

Procentese, A., Raganati, F., Olivieri, G., Russo, M. E., Rehmann, L., \& Marzocchella, A. (2018). Deep Eutectic Solvents pretreatment of agro-industrial food waste. Biotechnology for biofuels, 11(1), 1-12. https://doi.org/10.1186/s13068-018$\underline{1034-y}$

Rivera, X. C. S., Gallego-Schmid, A., Najdanovic-Visak, V., \& Azapagic, A. (2020). Life cycle environmental sustainability of valorisation routes for spent coffee grounds: From waste to resources. Resources, Conservation and Recycling, 157, 104751. https://doi.org/10.1016/j.resconrec.2020.104751

Rodrigues, C.; Viera, A. F. G. (2016). Estudos bibliométricos sobre a produção científica da temática tecnologias de informação e comunicação em bibliotecas. InCID: Revista de Ciência da Informação e Documentação, 7(1), $167-180$. https://doi.org/10.11606/issn.2178-2075.v7i1p167-180

Rolewicz-Kalińska, A., Lelicińska-Serafin, K., \& Manczarski, P. (2020). The circular economy and organic fraction of municipal solid waste recycling strategies. Energies, 13(17), 4366. https://doi.org/10.3390/en13174366

Sadhukhan, J., Dugmore, T. I., Matharu, A., Martinez-Hernandez, E., Aburto, J., Rahman, P. K., \& Lynch, J. (2020). Perspectives on "game changer" global challenges for sustainable 21st century: plant-based diet, unavoidable food waste biorefining, and circular economy. Sustainability, 12(5), 1976. https://doi.org/10.3390/su12051976

Secondi, L., Principato, L., Ruini, L., \& Guidi, M. (2019). Reusing food waste in food manufacturing companies: the case of the tomato-sauce supply Chain. Sustainability, 11(7), 2154. https://doi.org/10.3390/su11072154

Slorach, P. C., Jeswani, H. K., Cuéllar-Franca, R., \& Azapagic, A. (2020). Environmental sustainability in the foodenergy-water-health nexus: a new methodology and an application to food waste in a circular economy. Waste Management, 113, 359-368. https://doi.org/10.1016/j.wasman.2020.06.012

Sordan, J. E., Pimenta, M. L., Oprime, P. C., Rodrigues, Y. T., \& Marinho, C. A. (2021). Collaborative robotics: a literature overview from the perspective of production management. Revista Produção e Desenvolvimento, 7. https://doi.org/10.32358/rpd.2021.v7.516

Sousa, L. M. M., Firmino, C. F., Marques-Vieira, C. M. A., Severino, S. S. P., \& Pestana, H. C. F. C. (2018). Revisões da literatura científica: tipos, métodos e aplicações em enfermagem. Revista Portuguesa de Enfermagem de Reabilitação, 1(1), 45-54. https://doi.org/10.33194/rper.2018.v1.n1.07.4391

Tonini, D., Wandl, A., Meister, K., Unceta, P. M., Taelman, S. E., Sanjuan-Delmás, D., ... \& Huygens, D. (2020). Quantitative sustainability assessment of household food waste management in the Amsterdam Metropolitan Area. Resources, Conservation and Recycling, 160, 104854. https://doi.org/10.1016/j.resconrec.2020.104854

Van Buren, N., Demmers, M., van der Heijden, R., Witlox, F. Towards a Circular Economy: The Role of Dutch Logistics Industries and Governments. Sustainability (Switzerland) 8 (7), 1-17, 2016. https://doi.org/10.3390/su8070647

Vinck, K., Scheelen, L., \& Du Bois, E. (2019). Design opportunities for organic waste recycling in urban restaurants. Waste Management \& Research, 37(1_suppl), 40-50. https://doi.org/10.1177/0734242X18817714 


\section{DECLARATION OF CONTRIBUTIONS TO THE ARTICLE - CRediT}

\begin{tabular}{|c|c|c|c|c|c|}
\hline ROLE & KDuarte & TLima & LAlves & PRios & WMotta \\
\hline $\begin{array}{l}\text { Conceptualization - Ideas; formulation or evolution of overarching research goals } \\
\text { and aims. }\end{array}$ & $\mathrm{x}$ & & & & \\
\hline $\begin{array}{l}\text { Data curation - Management activities to annotate (produce metadata), scrub data } \\
\text { and maintain research data (including software code, where it is necessary for } \\
\text { interpreting the data itself) for initial use and later re-use. }\end{array}$ & $\mathrm{x}$ & $\mathrm{x}$ & $\mathrm{x}$ & & \\
\hline $\begin{array}{l}\text { Formal analysis - Application of statistical, mathematical, computational, or other } \\
\text { formal techniques to analyze or synthesize study data. }\end{array}$ & $\mathrm{x}$ & $\mathrm{x}$ & $\mathrm{x}$ & & \\
\hline \multicolumn{6}{|l|}{$\begin{array}{l}\text { Funding acquisition - Acquisition of the financial support for the project leading to } \\
\text { this publication. }\end{array}$} \\
\hline $\begin{array}{l}\text { Investigation - Conducting a research and investigation process, specifically } \\
\text { performing the experiments, or data/evidence collection. }\end{array}$ & $\mathrm{x}$ & $\mathrm{x}$ & $\mathrm{x}$ & $\mathrm{x}$ & $\mathrm{x}$ \\
\hline Methodology - Development or design of methodology; creation of models. & $\mathrm{x}$ & $\mathrm{x}$ & $\mathrm{x}$ & $\mathrm{x}$ & $\mathrm{x}$ \\
\hline $\begin{array}{l}\text { Project administration - Management and coordination responsibility for the } \\
\text { research activity planning and execution. }\end{array}$ & & & & & $\mathrm{x}$ \\
\hline $\begin{array}{l}\text { Resources - Provision of study materials, reagents, materials, patients, laboratory } \\
\text { samples, animals, instrumentation, computing resources, or other analysis tools. }\end{array}$ & $\mathrm{X}$ & $\mathrm{X}$ & $\mathrm{X}$ & $\mathrm{x}$ & $\mathrm{X}$ \\
\hline $\begin{array}{l}\text { Software - Programming, software development; designing computer programs; } \\
\text { implementation of the computer code and supporting algorithms; testing of existing } \\
\text { code components. }\end{array}$ & $\mathrm{X}$ & $\mathrm{x}$ & & & \\
\hline $\begin{array}{l}\text { Supervision - Oversight and leadership responsibility for the research activity } \\
\text { planning and execution, including mentorship external to the core team. }\end{array}$ & & & & $\mathrm{x}$ & $\mathrm{X}$ \\
\hline $\begin{array}{l}\text { Validation - Verification, whether as a part of the activity or separate, of the overall } \\
\text { replication/reproducibility of results/experiments and other research outputs. }\end{array}$ & & & & & $\mathrm{X}$ \\
\hline $\begin{array}{l}\text { Visualization - Preparation, creation and/or presentation of the published work, } \\
\text { specifically visualization/data presentation. }\end{array}$ & $\mathrm{x}$ & $\mathrm{X}$ & & $\mathrm{x}$ & $\mathrm{X}$ \\
\hline $\begin{array}{l}\text { Writing - original draft - Preparation, creation and/or presentation of the published } \\
\text { work, specifically writing the initial draft (including substantive translation). }\end{array}$ & $\mathrm{x}$ & $\mathrm{x}$ & $\mathrm{X}$ & & \\
\hline $\begin{array}{l}\text { Writing - review \& editing - Preparation, creation and/or presentation of the } \\
\text { published work by those from the original research group, specifically critical } \\
\text { review, commentary or revision - including pre- or post-publication stages. }\end{array}$ & $\mathrm{X}$ & $\mathrm{X}$ & & $\mathrm{x}$ & $\mathrm{X}$ \\
\hline
\end{tabular}

